\title{
Real Estate Market Stability: Evaluation of the Metropolitan Areas by Using Factor Analysis and Z-Scores
}

\author{
Andrius Grybauskas, Vaida Pilinkiene
}

\author{
Kaunas University of Technology \\ K. Donelaicio st. 73, LT-44029, Kaunas, Lithuania \\ E-mail.andrius.grybauskas@ktu.edu,vaida.pilinkiene@ktu.lt
}

cross $^{\text {ref }} \underline{\text { http://dx.doi.org/10.5755/j01.ee.29.2.19380 }}$

\begin{abstract}
This article is a modern approach to analysing the real estate market stability in today's era. Many statistical methods were used to measure price deviations, nonetheless, they were insufficient to identify the economic collapse in 2008. As sustainable growth in the real estate sector has become a major priority, some alternative measures to analyse market deviations should be developed. Most recent studies showed that home prices in San Francisco, New York, Vancouver and other cities are soaring up to new unprecedented historic heights. The issue on whether this price growth is another bubble risk factor remains debatable since more scientific evidence needs to be presented. Therefore, this paper develops a new "bubble" index which provides additional insights in the current market situation from a broader perspective. The empirical research, which was conducted on four different metropolitan areas worldwide, which demonstrated an outstanding home price growth over the period 2008 to 2016. By applying factor and z-score analysis to seven different sub-indexes and aggregating them all into one, this paper developed the methodological framework that allowed to assess whether there is an under/over value situation in the real estate market. The research results have confirmed that 4 metropolitan areas (San Francisco, Vancouver, London and Sydney) are indeed in the bubble risk zones, which can lead to a market correction or even a new recession. The research suggests that although it is difficult to compare model accuracies, employment of factor analysis and z-score methods provides strong predictability capacity since it perfectly mimics the prior economic crisis and leads to the results somewhat similar to those obtained by employing the UBS bubble index.
\end{abstract}

Keywords: Real Estate; Sustainable Growth; Factor Analysis; Price Bubble; Indicator; Stability; Z-Scores.

\section{Introduction}

After the economic collapse in 2008, the real estate sector has become a centre of discussion when talking about sustainable future. Ever since, much has been done to revive the economy: national governments injected new money to keep GDP growth stable and implemented stricter regulations for banks issuing loans and other derivatives. However, most recent skyrocketing prices in the housing market question whether the actions were sufficient. The USA "Shiller" house price index almost reached its precrisis level, which in 2008 was equal to 121.4 index points, and in 2016 - to 118.4 index points, that is 3 points lower than the pre-crisis level. Growth rates were as high as 9.6 percent and averaged about 5 percent within the time period of 2008 - 2016. Even more drastic changes occurred in the UK where the pre-crisis levels were surpassed by 46 index points and on average prices grew at about 5 percent rate. The worst situation within the post-crisis period was recorded in Canada, where prices exceeded previous bubble prices by 82 index points. Last but not least is the situation of Australia where house prices grew by 33 index points above the previous bubble price level.

Although price growth is usually considered a positive trend, this particular situation should be assessed cautiously. A balanced growth in the RE market is usually between 3 6 percent (if inflation is around $1-2 \%$ ); otherwise a big surge in prices makes people go in debt faster than they are capable of dealing with indebtedness as the annual growth of average income cannot adjust so quickly. Later on, this usually leads to an economic collapse since domestic demand cannot satisfy growing prices and people are not able to pay off their mortgages.

All of the above-mentioned countries also showed high volatility. The USA national "REIT" (Real Estate Investment Trust) index annual return in the time period of 2008-2016 was extremely unstable and ranged from the max value of 30 percent in 2009 to the min value of 2 percent in 2015. The UK followed a similar scenario: the biggest return was in 2008 when it reached 28 percent, while in 2011 the market experienced the 2 percent loss. Canadian $\mathrm{RE}$ market was even more volatile ranging from the max value of 46 annual index return to the minimal value of 2 percent, while Australia fell in the brackets of -46 percent of annual return to 18 percent growth. Whether this volatility and steep price growth can be referred to as a possibility of a new bubble, scientific research needs to be conducted.

Following authors Merling \& Baker (2016), Belke \& Wiedmann (2005), Himmelberg et al., (2005), Andrew (2003), Frew \& Wilson (2003), Chen \& Qianjin (2010), Sivitanidou (2008), Myrmo (2012), Pressley (2016), Herbert \& Gibler (2014), carried out an extensive analysis of the housing market stability by considering confined variables, such as price, homeowner vacancy, rental vacancy, annual job growth, etc. The discussion was centred on whether solitary indicators are informative enough to 
lead to professional conclusions about the state of the market and which variables are reliable enough to be used while trying to identify uprising market problems and fluctuations.

Some of the scholars, like Marsden (2015), Bork (2014), Kulikauskas (2016), Keizeriene (2016), Coskun \& Jadevicius (2017), performed complex modelling of the RE market in order to avoid inaccurate predictions with solitary variables. The tools like descriptive indicators, econometric modelling, time series, regression and factor analysis were employed, and some authors managed to detect housing problems prior a bubble burst, but others did not, which calls for deeper research in this area. Many of the studies mentioned-above focused solely on price changes to evaluate the bubble or created models that use too few or only objective, numeric data to explain market conditions, while subjective factors like people's perception was left behind. Furthermore, many models are based on regression which itself is a mathematical approximation of reality that leaves the natural movement of prices behind. New methods of Z-scores and factor analysis have shown many promises in prior works determining solvency issues in banks and business companies. Leaning on the results of previous studies, these methods can be considered applicable to housing markets.

Therefore, the aim of this paper is to create a sophisticated indicator that is capable of measuring the real estate market stability. The paper focuses on not only single variables but also sub-indexes and such subjective data as people's perception of the current economic state. The methods of the research include a comparative literature analysis, correlation analysis, variance analysis, factor analysis, Z-scores, "KMO" and "Barlett" tests, benchmarking and weighted indicator development.

\section{Theoretical and Empirical Background}

To find the most appropriate variables for developing of the model, firstly it is important to identify an accurate definition of the market stability itself. According to the $\mathrm{ECB}$, in order to keep the market stable, 3 crucial conditions have to be met:

a) all resources must be allocated effectively through the probability of usability;

b) supply must smoothly adapt to technological and demand change;

c) markets motivation is that participants that are productive are motivated and technological growth is fostered

Both supply and demand function properly on condition quantity and price are balanced and adopt without a major change. Yu (2008) provided her own definition of the stable market: it is the ability of the market to absorb huge amounts of trade deals without causing too many fluctuations in price. Thus, in both cases price and quantity are the major market stability determinants. For this reason, in one form or another, they have to be included in the model designed for market stability measuring.

But the price itself does not tell much about whether the market is stable. Thus, price should be employed as a ratio. As it was clearly noted by Belke \& Wiedmann (2005), to determine the fair and sustainable value of a house, price to earnings ratio should be employed as a useful measure. The gap between the $\mathrm{P} / \mathrm{E}$ shows the shrinkage of the inner demand since fewer and fewer people are able to afford housing. The income is referring to the average household income per year; in other words, this ratio tells us for how many years a person needs to work in order to afford an apartment. The best ratio norms usually fall into the interval between 3 and 8 . Any ratio higher than 8 is considered a difficult situation for an average income earning person. Similar to this, price to rent ratio provides another confirmation of the worsening situation in a city. The bigger is the gap, the more people will be renting apartments rather than buying overvalued property. Typically, this ratio should not be higher than 17 , otherwise, a sustainable rent level is almost impossible.

These two above-introduced indicators do have certain limitations. Himmelberg et. al, (2005) argue that P/I and P/R ratios on average fail to mirror the conditions in the $\mathrm{RE}$ market (mainly, due to different interest rates set by central banks). Thus, past deviations might not be an indication of misalignments. Andrew (2010) postulates that deeply regulated markets provide a distorted view of these ratios. It is worth mentioning that these ratios do not account for the change in housing quality. For example, citizens might start to prefer higher quality buildings which are more expensive. Such change in perception shows that P/I gap is rising, but it would be false to interpret that the change is caused by speculation. For this reason, the above-mentioned indicators should be considered in conjunction with other analytical tools.

The third important variable is inside the city property price to outside the city property price ratio. Frew \& Wilson (2003), and Chen, \& Qianjin (2010) published two studies on this matter. In both cases, a hedonistic model was developed to measure to which extent a city's central location affects the prices of apartments. Both of the studies concluded that even if the price difference should occur, the size of the difference matters. If inside the city property price to outside the city property price ratio is extremely high, it could mean that the city centre is overcrowded, and the local government is not doing its job well in developing the infrastructure. In an effectively working market, the difference in this ratio should be as small as possible.

When developing stability measures, many researchers omit external stability determinants. In her theoretical work about real estate demand and supply, scientist Sivitanidou (2008) firmly states that population is one of the major shocks that the housing market can face. It literally shifts the demand to a new position sharply influencing the stability of the market. Similar findings were obtained in Myrmo's (2012) dissertation where the author concludes that the positive population growth leads to an increased demand, which, in turn, initiates higher housing prices and enhances the bubble formation risk. Therefore, population should also be included in the model as a RE market stability determinant alongside price and quantity. Although some researchers argue that population is not linear and $100 \%$ positive variable to housing prices direction. Pressley (2016), who studied Australian market, found an interesting but contradictory pattern. Ever since the 2000s Australian population has grown by an average of 1.7 percent per annum. According to the official city property data for the 
past 15 years, Darwin (with the smallest population mass) was the best-performed city in terms of price rise, while Sydney and Melbourne (with the biggest population mass) had the least growing prices. In spite of some contradictions, in general cases population is a strong determinant of rising property prices and should be considered as a prominent contributor to rising housing costs. As more households form the more demand livable square feet grows.

Household expectations towards prices is the fifth important factor of the real estate market stability measuring. As Sivitanidou (2008) wrote in her book, investors are heterogeneous; by buying estate, they are optimists who in the future will become pessimists and will try to sell their properties to someone else who will be an optimist at that time. If the whole investor society admitted that the market is overvalued, then there would not be anyone to sell the property to, which, in turn, would lead to market corrections. A more practical-empirical study on this topic was conducted by Snieska et al., (2011), who employed the method of expert evaluation to verify the impact of the most important housing price determinants. $85.7 \%$ of the experts agreed with the proposition that investor's and consumer's expectations heavily shape the pricing of real estate. For this reason, this input is especially important in measuring the market condition.

The quantity variable in the real estate market attributes to new construction of the following year. According to Herbert \& Gibler (2014), construction of a new living area in established neighbourhoods generally has a positive effect on existing apartment prices. The prices of already existing houses fall when new similar-sized houses are constructed nearby. In general terms, a new property is a direct antidote to rising property prices. The more stock available to the population a city has, the lower is the chance of a new real estate bubble occurrence. It should be noted that if a new construction attracts more people with more money to the certain area, the surrounding establishments improve, and property values might go up because of the rising demand. In most general cases, additional supply lowers the prices of older buildings.

Another significant component is outstanding mortgages. Some researchers used descriptive statistics and questionnaires trying to find out whether the real estate industry professionals recognise the impact of mortgages on housing price changes. Almost all respondents agreed that loan conditions affect real estate values and speed of sales. Similar results were obtained by Snieska et al., (2011). In their research, $74.2 \%$ of the experts explained that housing buyers who can take several bank loans buy their housing for living and purchase one more apartment subject for sale in case prices soared, thus creating a speculation loop. Nevertheless, while analysing mortgages, it is important to remember that there has to be a reference point at which the volume of debt may get too big for a country to handle. A very popular approach, followed by the IMF, is analysing of debt by comparing it to GDP. Pinheiro (2009) implemented a three-step procedure to assess the extent of exposure to real estate in commercial banks. Leaning on the differences between the most vulnerable banks and the rest of the sample, he noticed that the banks with fast loan growth followed by high cost/income ratios are the most likely to experience a deterioration in their soundness. For this reason, it is relevant to measure the change in the mortgage to GDP as ratio rather than a solitary variable.

Regression analysis with advanced econometric modelling has been the golden standard for studying the real estate. Keizeriene (2016) analysed Lithuanian housing market by weighing prices to find out how much they deviated from fundamental prices, but this model is somewhat limited as it only regresses one variable and does not account for error correction. Kulikauskas (2016) used regression in conjuncture with error correction term. He studied several statistical indicators $(\mathrm{P} / \mathrm{R}$ ratio and $\mathrm{P} / \mathrm{E}$ ratio with Hodrick-Prescott filter) separately to get the view of the market condition and also estimated market equilibrium equations. In his regression model, the author used the variables of construction input, price indices, GDP per capita, population, mortgage loan stock and real mortgage interest rates. But no variables of population or expectations, which are considered highly important, were included in the model. By researching Czech housing bubble, Cadil (2009) managed to include population variable in his OLS model, but the main problem with his method was that the author made the first difference of the logarithms to get stationary data, which led to substantial loss of information. The regression model, developed by Coskun \& Jadevicius (2017), assessed the interdependence between housing prices and a series of eight explanatory variables. Nevertheless, the regression explained only $50 \%$ of the variance.

As regression equations have many drawbacks, it is worth having a look at other forms of statistical methods, one of which is factor analysis. This methodology can be found in the UBS's (2016) annual reports. To measure pricing in the housing market, this method employs standardized city sub-indices: $\mathrm{P} / \mathrm{E}$ and $\mathrm{P} / \mathrm{R}$, change in mortgage/GDP ratio, change in construction/GDP ratio and relative price-city-to-country indicator. By using principal component method, it benchmarks the model with P/E and $\mathrm{P} / \mathrm{R}$ measures as they explain the largest part of variance and aggregates a weighted index. Although the model itself is very promising, it does miss very important variables: population and expectations. Another study was conducted by Bork \& Muller (2014), who employed factor analysis to predict the future prices on a large information set involving more than 100 macroeconomic and financial variables. The authors concluded that forecasting power of the three-factor model is robust and has strong predictability.

A more similar approach to what this paper is trying to achieve was proposed by Pitros \& Arayici (2016). Their study was driven by the normal distribution theorem coupled with the case study approach. The authors analysed UK market data, and quite successfully managed to recreate bubble bursts throughout the years. However, their model included only four elements (house prices, debt ratio, gross lending and housing completions), which is insufficient to explain the complexity of the market. Klotz et al., (2016) applied the direct capitalization approach through the weighted average cost of capital (WACC) to identify real estate bubbles over the period from 1999 to 2012 alongside VAR and VECM models to investigate short- and long-run dynamics. The model was somewhat limited in the sense 
that it only considered the return from rent rates and how much they deviated from their fundamental values.

One of the more promising method that has rarely been used in the housing market is the z-score. As z-scores are the difference between a variable and a mean divided by standard deviation it is a very effective method to measure the disruptions in the market. Hughes et al., (2010) used the Altman's Z-score test to predict the bankruptcy and solvency problems for the firms. It managed to successfully identify future bankruptcies with a $90 \%$ accuracy rate. The substantial results were also achieved by Meeampol \& Lerskullawat (2014), who measured the financial distress of the listed companies. The results of their analysis reveal that z-score models can completely predict the signs of a possible bankruptcy that may occur at an $89 \%$ accuracy rate. A z-score model for real estate companies was also developed by Yi (2012). A sample of China's 40 listed real estate companies was chosen, and risk analysis was employed. Although the prediction accuracy rate was lower than $90 \%$, that is still very high.

Despite the existing variety of scientific research, it can be stated that all the above-mentioned variables indeed have a significant effect on the property value and can be introduced in the model. Secondly, a more comprehensive model can be built to measure the real estate market stability as previous methods miss one or two important aspects in the process. Z-score method has not been widely used to create a price bubble index, although it has a robust track record in being of high accuracy. Leaning on these findings, a niche for the research was discovered.

\section{Research Methodology}

The analysis was based on seven following techniques: sub-index calculations, "KMO" and "Bartlett" tests, correlation analysis, benchmarking, total variance analysis, data standardization and $\mathrm{z}$-scores.

For the factor analysis to be carried out properly, the following assumptions have to be met:

a) there cannot be any outliers in the data set; at the start of the procedure, the data set must be standardized;

b) an adequate sample size must be reached; there cannot be more components than actual samples;

c) perfect collinearity cannot exist; a particular data set sample can be correlated, but not to the perfect correlation that is equal to -1 or to 1 ;

d) homoscedasticity among the variables is not required;

e) the data cannot be nominal or ordinal, every single sample must fall into an interval form. A "Varimax" rotation will be employed to carry out the factor analysis.

All of the data used in this paper were collected from official government data websites (statcan.gc.ca, nationwide.co.uk, abs.gov.au, census.gov) and other external databases, like zillow.com, numbeo.com, JLL and trullia.com.

$\mathrm{P} / \mathrm{E}$ ratio is the first variable selected for the analysis. It is the basic measure for apartment purchase affordability (lower is better). It is calculated as the ratio of median apartment prices to median familial disposable income, expressed as years of income. The formula assumes and uses net disposable family income, defined as $1.5 *$ the average net salary. Median apartment size is 90 square meters; price per square meter is the average price of a square meter inside and outside the city centre.

$\mathrm{P} / \mathrm{R}$ ratio is the average cost of ownership divided by the received rent income. In most cases, lower values suggest that it is better to buy rather than rent, while higher values suggest that it is better to rent rather than buy. This formula to estimate rent per square meter assumes that a 1-bedroom apartment has 50 square meters, while a 3-bedroom apartment has 110 square meters. It doesn't take into account taxes or maintenance fees.

Mortgage as Percentage of Income is a ratio of the actual monthly cost of the mortgage to take-home family income (lower is better). Average monthly salary is used to estimate family income. It assumes that $100 \%$ mortgage is taken on 20 years for the house (or apartment) of 90 square meters when the price per square meter is the average of price inside and outside the city centre. Since all three of these sub-indexes are very insightful and quite often in a standalone mode are a good measure of markets performance it is rational to do an overview of all of them separately before going into a deeper analysis.

However, the interpretation of ratio is a slippery slope. So as to have an objective analysis of the price to income ratio results, 4 different zones are established. The optimal values for this sub-index fall into the first interval with values under 5 . If that is not the case, three more overvalued zones are created. The second one is between 5 and 8 . In this case, the apartment is considered quite affordable as the mortgage percentage of a citizen's income is between from 35 to 65 . The third overvalue zone covers the values from 8 to 12. At this point, to afford a house, a person needs to take a loan which takes up from 60 to 90 percent of his/her income. The fourth zone covers the values from 12 to 20 . In this case, mortgage loans take more than 90 percent of a person's income, and the future of real estate is bleak. Finally, the values over 20 indicate a bubble area. It should be noted that the negative values could also mean that real estate is undervalued. For price to rent values, two measures are graphed: the values for inside the city centre and outside the city centre, with a touch of mortgage to loan percentage graphs as diagrams behind them. For inside and outside the city centre values, it is important to be as close as possible, otherwise, it means that the local government is not doing its job well in terms of city's strategic planning. As a result, a real estate bubble may arise. High $\mathrm{P} / \mathrm{R}$ ratio values indicate the property overvalue situation in the city.

To accumulate the data on the expectations of price growth, an international survey ING Homes and Mortgages September 2016 was used. This survey was conducted by Ipsos between 3 June and 24 June 2016 by employing the Internet-based polling. European consumer figures in this survey are presented as an average, weighted to take a country's population into account. The main question asked was "What is your opinion regarding current housing prices where you live?". The results are displayed as a percentage of those who think that housing prices in their country or city are overvalued.

The growth of population is considered as a factor of price growth. Therefore, if the population is rising, price growth in some cases can be legitimized as a rational growth. Similar principals are applied to the construction data set, which is the new square meter of space being given 
as a supply of apartments throughout the year 2016 to compensate a higher growth.

In Formula (1), $r$ denotes the correlation matrix values with $\mathrm{x}$ and $\mathrm{y}$ variables over $\mathrm{n}$ pairs of data. The correlation coefficients are calculated by using Pearson's methodology. In Bartlett test Formula (2), $\mathrm{k}$ stands for the sample, $\mathrm{N}$ is a sample size, $\mu$ is a mean, $\sigma$ depicts standard deviation, and $\mathrm{s}$ denotes sample variance. For weight calculations, variance and standard deviation are denoted in Formula (3); $\mathrm{W}_{\mathrm{i}}$ are the weights (which are the expected value of the squared deviation from the mean) acquired through the total variance matrix; $\mathrm{Bi}$ is the $\mathrm{Z}$-score value of the variable data for particular year. In the last formula set (4), zd stands for z-score which implies the difference of a variable from the mean divided by the standard deviation. For KMO and Bartlett's tests, the research norms to be reached are KMO $>0.5$ and Bartlett $<0.01$, otherwise, the hypothesis has to be rejected, and the factor model is not viable.

$$
r=\frac{\mathrm{n}\left(\sum \mathrm{xy}\right)-\left(\sum \mathrm{x}\right)\left(\sum \mathrm{y}\right)}{\sqrt{\left(\mathrm{n} \sum \mathrm{x}^{2}-\left(\sum \mathrm{x}\right)^{\wedge} 2\right)\left(\mathrm{n} \sum \mathrm{y}^{2}-\left(\sum \mathrm{y}\right)^{\wedge} 2\right)}}
$$

$$
\begin{aligned}
& \mathrm{T}=\frac{(\mathrm{N}-\mathrm{k}) \operatorname{lns}_{\mathrm{p}}^{2}-\varepsilon_{\mathrm{i}=1}^{\mathrm{k}}\left(\mathrm{N}_{\mathrm{i}}-1\right) \operatorname{lns}_{\mathrm{p}}^{2}}{1+(1 /(3(\mathrm{k}-1)))\left(\left(\varepsilon_{\mathrm{i}=1}^{\mathrm{k}} \frac{1}{\left(\mathrm{~N}_{\mathrm{i}}-1\right)}-1 /(\mathrm{N}-\mathrm{K})\right.\right.} \\
& \sigma=\sqrt{\frac{\sum(\mathrm{X}-\mu)^{2}}{\mathrm{~N}}} \quad \operatorname{Var}_{x}=\sum(\mathrm{X}-\mu)^{2} \quad \frac{1}{\mathrm{n}} \sum_{\mathrm{i}=1}^{\mathrm{n}} \mathrm{W}_{\mathrm{i}} \mathrm{B}_{\mathrm{i}} \\
& \mathrm{KMO}_{\mathrm{j}}=\frac{\mathrm{E}_{\mathrm{i}=\mathrm{j}} \mathrm{r}_{\mathrm{ij}}^{2}}{\mathrm{E}_{\mathrm{i}=\mathrm{j}} \mathrm{r}_{\mathrm{ij}}^{2}+\mathrm{E}_{\mathrm{i}=\mathrm{j}} \mathrm{u}} \quad \mathrm{zd}=\frac{(\mathrm{x}-\mu)}{\sigma}
\end{aligned}
$$

If the assumptions of the factor analysis are successfully met, the "Varimax" procedure can take place. It creates a variation matrix with weights, and a new derivative tool can be obtained to measure the RE market stability. The weights can be attributed to each individual sub-index according to the amount of variance each variable explains, and eventually the weighted index can be summed into one aggregate measure (OECD "Handbook on Constructing Composite Indicators" 2008). The benchmark procedure is carried out according to Z-scores output distribution. This benchmarking technique is especially efficient because it takes into account the uniqueness of the housing market attributes in a particular region for the period between 2002 and 2016. Merely benchmarking P/E values might distort the reality since some areas have historically had high or low ratios. Therefore, the method used by "UBS", one of the biggest European real estate investment funds, is less accurate.

The intervals are displayed in Figure 1. The neutral position values fall into the interval from -0.5 to 0.5 ; here standard deviations accumulate to $34.13 \%$ of all the data. Alongside, the second quantiles fall into the interval from 1.5 to -0.5 for undervalue, and into the interval from 0.5 to 1.5 for overvalue positions, with the $17.06 \%$ accumulation respectively. In this position, the mortgage debt of households as well as $\mathrm{P} / \mathrm{E}$ and $\mathrm{P} / \mathrm{R}$ ratios are at unusual levels that should cause suspicion. Finally, the bubble positions are at $<-1.5$ and $>1.5$, i.e. at the very edges of the quantiles, with the $15.87 \%$ accumulation respectively.

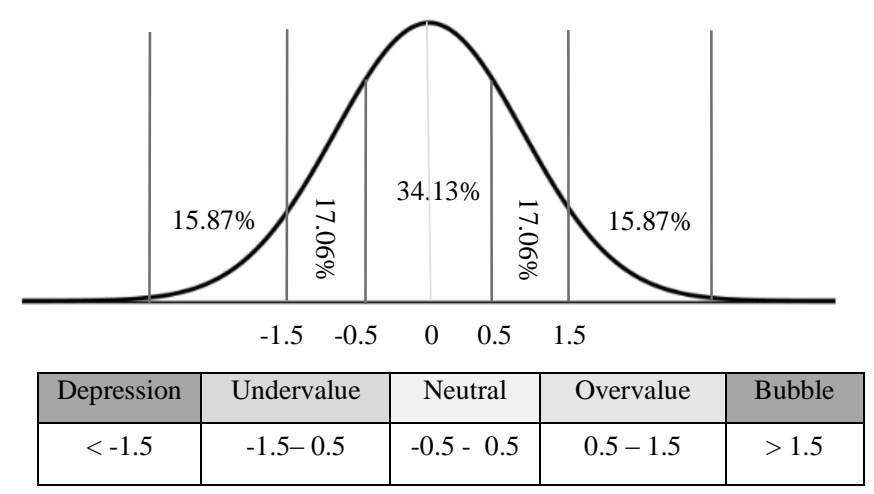

Figure 1. Benchmark Intervals for the Analysis of Z-Scores

Depending on where the indicator for a particular country lands on this constructed scale, the conclusions on whether a price bubble exists can be made. This method is also more rational than that used by Wooldridge (2002), who employed the regression analysis to calculate HPI (housing prices), solely because the OLS method approximates the data, leaving the natural movement of economy subtracted from the model. Similar problems with regression can be found in Kulikauskas's (2016) study, where two coefficients were insignificant to predict HPI, and error correction had to be done alongside, which again distorted the real empirical values of the market just in order to fit the mathematical model criteria. Keizeriene's (2016) dissertation did not even include more advanced methods to account for more natural market movement and simply used a linear regression, while the method of normal distribution theorem, used by Pitros \& Arayici (2016), included too few variables to explain the complexity of the market. The same problems were found in Klotz et al., (2016) study, were lag VAR models only included Euribor rates, lending and net value of return from rent. This is very inaccurate as return rates may fall for many other reasons, such as old unrepaired property conditions. Therefore, a Z-score approach is an alternative to economists for a more natural price fluctuation determination.

\section{Research Results}

The research was based on yearly data (for the period between 2002 and 2016 since this was the only data available at that time). The data was collected from various statistical databases for 4 most active metropolitan areas around the world: London, Sydney, Vancouver and San Francisco. These cities were chosen for a reason: through the eight-year timeline (2008-2016), they demonstrated an extreme growth in apartment and housing prices. In only eight years, San Francisco house prices surged up by $77 \%$ to $1,023,500$ euros per house, while the average US home prices only reached 725,350 euros. Vancouver prices grew about $66 \%$ to 767,736 euros, while on average prices stayed at 464,000 euros. London felt a $50 \%$ price growth, and the prices reached 586,000 euros, while the UK's average house price remained at 258,000 euros. Finally, Sydney grew about $64 \%$ to a new record high of 930,000 euros, while the average homes balanced at 376,000 euros per house. Because of extremely high market activity and fast price growth, these 4 mentioned-above cities were a perfect selection while trying to identify new bubble formation 


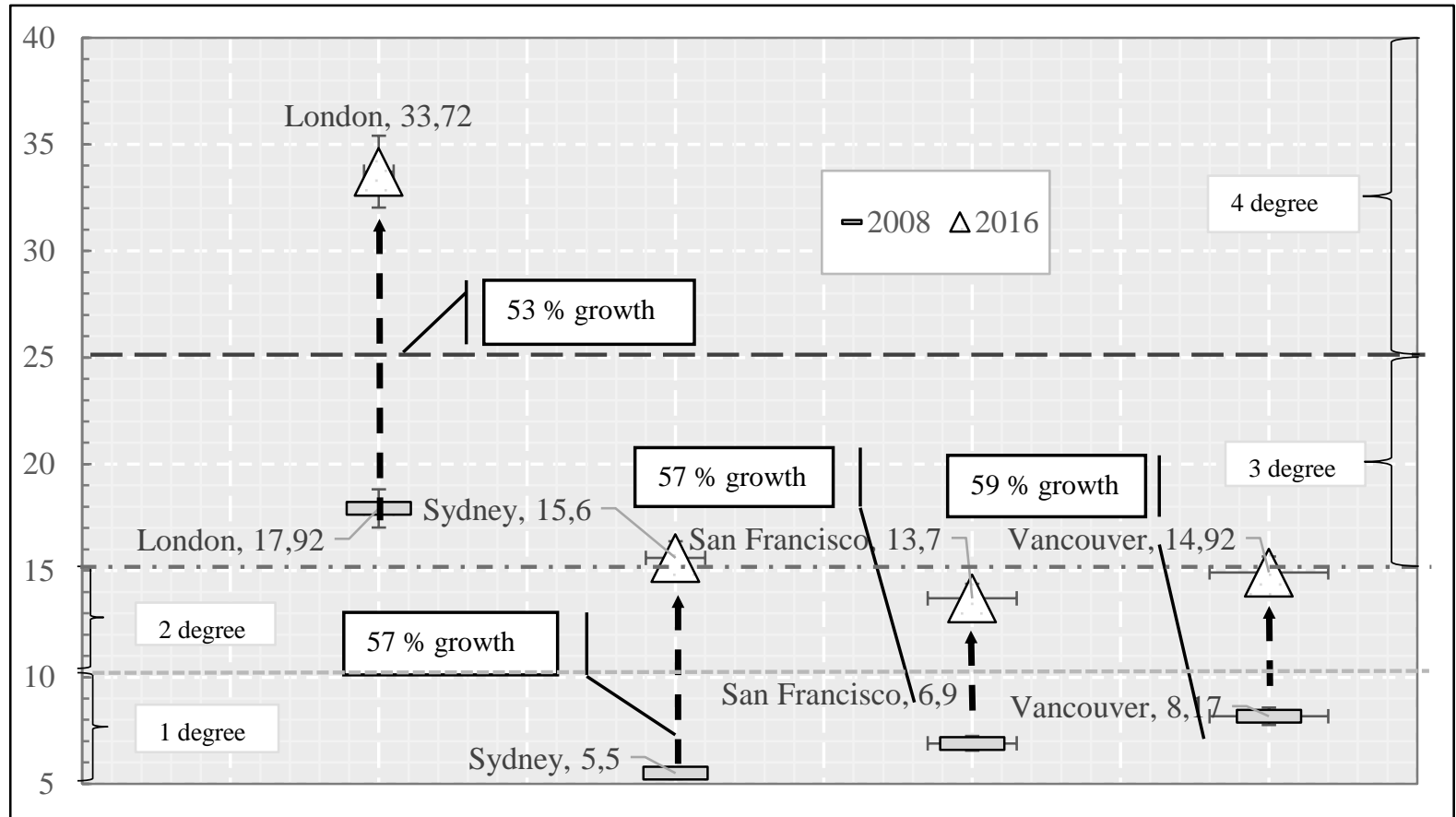

Figure 2. Vancouver, Sydney, London and San Francisco, Nominal Average Annual Income to Nominal Average Annual Apartment Prices for 2008-2016 (compiled by the author according to https://www.trulia.com, https://www.ons.gov.uk; http://www.abs.gov.au/; www.numbeo.com; http://www5.statcan.gc.ca/)

locations. Firstly, price to earnings indicator was observed in standalone to conclude whether there was any reason to measure instability of the market. If this $\mathrm{P} / \mathrm{E}$ indicator had been at its recommend level, there would have been no need to carry out the further economic analysis. The graph with $\mathrm{P} / \mathrm{E}$ values is depicted in Figure 2. The findings suggest that abnormal situations have occurred in recent years. The data show that the P/E difference in Sydney, San Francisco, Vancouver and London have grown by $57 \%, 57 \%, 59 \%$ and $33 \%$ respectively. This shows that an average citizen has its housing affordability situation worse off in 2016 than in 2008 since it needs full 33-years in London, 15 years in Sydney, 13 years in San Francisco and 15 years of average annual income to be able to afford an average sized apartment. This volatility is a sign of another economic bubble. The P/R measure with mortgage rates did show similar trends to $\mathrm{P} / \mathrm{E}$. The demand of the new RE was shrinking from within the cities as in most cases the mortgage rates in 2016 took almost $100 \%$ of the average income, and in some cases surpassed it. The situation in London was most extreme of all since the mortgage rates took up to $192 \%$ of the average nominal income. The mortgage cover rates in Sydney were $89.14 \%$, in Vancouver $86.63 \%$, and in San Francisco $81.88 \%$. In most cases, mortgage cover rates grew steadily over the period of 8 years, which indicates a lower stability of the RE market as the limits of price growth have already been reached and are being over-stretched. Although the rent rate was also up to par with extreme values, in Figure 3 the values were compared to see whether the city strategic planning had any impact on growing prices. While the prices of rent inside and outside three cities were sustainable, and no substantial differences were suspected, London had a huge gap in its rent prices, which could have been determined by the poor municipal strategic planning and by huge population intake rates. Out of all four cities, San Francisco had the best mortgage cover rates and price to rent values, although they were still very high.

Table 1

Descriptive Statistics of 4 Analysed Metropolitan Areas

\begin{tabular}{|c|c|c|c|c|}
\hline & \multicolumn{2}{|c|}{ London } & \multicolumn{2}{|c|}{ Sydney } \\
\hline & Mean & Std. Dev. & Mean & Std. Dev. \\
\hline $\mathrm{P} / \mathrm{E}$ & 17,0787 & 6.26739 & 7.7553 & 1.82386 \\
\hline $\mathrm{P} / \mathrm{R}$ & 28.8764 & 5.283 & 20.4707 & 1.3377 \\
\hline $\mathrm{C} / \mathrm{C}$ & 1.6239 & 0.12377 & 2.6384 & 3.85395 \\
\hline M/Gdp & 0.00610 & 0.0398006 & 0.0356 & 0.08401 \\
\hline Expec & 72.0667 & 6.95359 & 72.8 & 7.89394 \\
\hline Const & $1.2 \mathrm{E}+11$ & $166 \mathrm{E}+10$ & 198.5333 & 19.6682 \\
\hline \multirow[t]{3}{*}{ Pop } & 7648388 & 499278 & 820618 & 25808.6 \\
\hline & \multicolumn{2}{|c|}{ Vancouver } & \multicolumn{2}{|c|}{ San Francisco } \\
\hline & Mean & Std. Dev. & Mean & Std. Dev. \\
\hline $\mathrm{P} / \mathrm{E}$ & 9.9107 & 1.2141 & 8.0247 & 1.83352 \\
\hline $\mathrm{P} / \mathrm{R}$ & 18.9416 & 3.39045 & 19.6707 & 4.74724 \\
\hline $\mathrm{C} / \mathrm{C}$ & 1.21606 & 0.0566657 & 3.60533 & 0.336397 \\
\hline M/Gdp & 0.10079 & 0.2275209 & 0.027973 & 0.053457 \\
\hline Expec & 67.2 & 17.46916 & 72.3333 & 6.16055 \\
\hline Const & $7.61 \mathrm{E}+10$ & $7.73 \mathrm{E}+09$ & 845846 & 126004 \\
\hline Pop & 2247450.933 & 211234.645 & 820786 & 25682.6 \\
\hline
\end{tabular}

After application of the "Varimax" rotation, the positive Kaiser-Meyer-Okin and Bartlett test values were obtained, which let the analysis to proceed since the values fell into the statistical norms ("Kaiser-Meyer-Okin" > 0.5, and "Bartlett" < 0.01, as depicted in Table 2). Two eigenvalues were created for all cities with two factors, and no perfect multicollinearity was detected in the correlation matrix analysis. By using the extraction method principal component (PCA), SPSS generated a total variance matrix which summed to 100 (as demonstrated in Table 2 below). From this table, the weights for calculation of the variable impact on the aggregate index were obtained. In all cases, price to earnings and price to rent explained the largest proportion of the variance in all four cities under research: in London and San Francisco, they explained up to $58 \%$, in 
Vancouver - $53 \%$, and in Sydney - $47 \%$ of the variance, which exceeded or was close to half of all the variance in the analysed model.

The reasons why $\mathrm{P} / \mathrm{E}$ and $\mathrm{P} / \mathrm{R}$ ratios can be considered reliable solitary indicators in general is that they explain the largest proportion of the variance. When analysing London
Governments in these countries injected money to facilitate growth and the central banks reduced the interest rates to their lowest positions to reverse the effects of the prior crisis. However, investors were unsure of market future trends for about 5 years. It was not certain whether it was reliable to invest in construction business once again, and

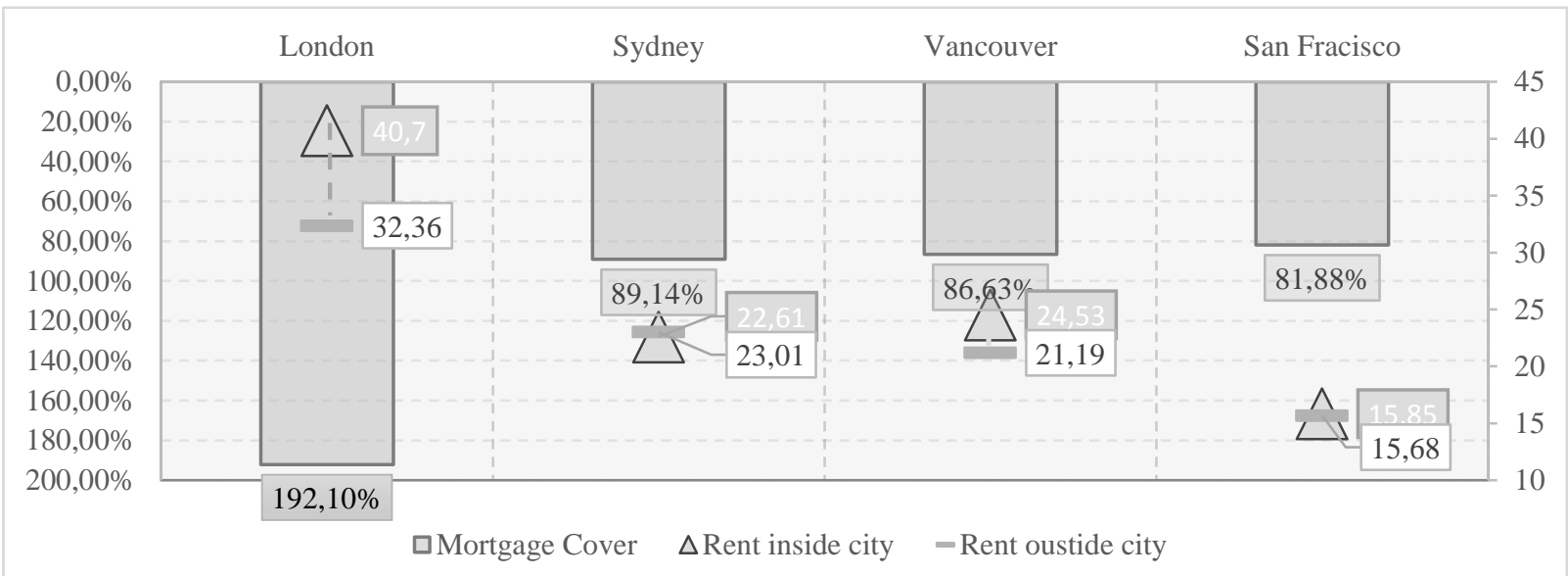

Figure 3. Vancouver, Sydney, London and San Francisco Mortgage Rate in the Average Income and Rent to Price Indicator (compiled by the author according to: https://www.trulia.com, https://www.ons.gov.uk; http://www.abs.gov.au/; www.numbeo.com;)

city, the second factor generated that expectations (0.931) and mortgage to GDP change (-0.815) had a contrary impact on each other, which means that when expectations rise fewer people take out housing loans. The first factor, $\mathrm{P} / \mathrm{E}$ (0.962) had the same growth direction, but a faster growth rate than population (0.908). In Vancouver, the second factor showed that mortgage to GDP change (0.788) and P/E $(-0,728)$ had an opposite dependency. The first factor implied that $\mathrm{P} / \mathrm{R}$ (0.914), population (0.909) and construction (0.884) all grew at a similar pace in one direction. For Sydney, the first factor indicated that expectations (0.852), construction (0.842) and P/R (0.833) had a very close positive movement, while within the second factor city/country ratio (-0.841) and mortgage to GDP change (0.902) had an opposite movement effect. For San Francisco, the first factor revealed that city/country price difference (0.897), P/E (0.864) and P/R (0.817) all had strong movement upwards together, while the second factor implied that mortgage to GDP and population had opposite effects on each other.

When statistical analysis results for the stability index were obtained, it was important to know how robust and reliable the model truly was. A strong argument in favour of this indicator's accuracy was the fact that it perfectly mirrored the RE price bubble that occurred from 2002 to 2008. Secondly, 5 statistical assumptions for factor analysis were fulfilled, and the optimal norms for KMO and Bartlett's test were successfully achieved. Thirdly, z-score benchmark method had an effective track record of $90 \%$ accuracy rate in previous studies conducted on companies and banks. Fourth, as z-score are a difference between the variable and the mean divided by standard deviation, it can hardly be wrong in showing the amplitude of movement. Therefore, this index in conjecture with others is a good place to look for real estate market stability insight.

While analysing the results graphed in Figure 4, it was noticed that there was a doubt period in between 2009-2014. this uncertainty led to the drops in the stability index. In 2016, it can be argued that the real estate market stability at these 4 particular metropolitan areas was at risk. As shown in Figure 4, San Francisco reached 1.56, Vancouver -1.03 and Sydney - 1.45 index points; all of the cities had already been in overvalued positions, which indeed was a concerning factor, but the most abnormal situation was found at London where the index reached a 2.14 position. As the influx of people came to the UK's biggest city, it made the current situation of the real estate market extremely unstable.

Table 2

Variation Matrix, KMO and Bartlett Results

\begin{tabular}{|c|cccc|}
\cline { 1 - 2 } Var. & London & Francisco & Vancouver & Sydney \\
\cline { 1 - 1 } P/E & 59,293 & 59,937 & 53,77 & 47,846 \\
\cline { 1 - 1 } P/R & 23,773 & 17,693 & 18,495 & 24,123 \\
\cline { 1 - 1 } Center/Out & 11,933 & 11,509 & 11,457 & 12,161 \\
\cline { 1 - 1 } M/GDPc & 2,201 & 5,26 & 9,94 & 9,352 \\
\cline { 1 - 1 } Expect. & 1,601 & 4,283 & 4,601 & 3,567 \\
\cline { 1 - 1 } Cons. & 0,949 & 1,141 & 0,944 & 1,625 \\
\cline { 1 - 1 } Pop. & 0,251 & 0,177 & 0,793 & 1,326 \\
\cline { 1 - 1 } Sum & 100 & 100 & 100 & 100 \\
\cline { 1 - 3 } Barlett test & 0.00 & 0.00 & 0.00 & 0.00 \\
\cline { 1 - 3 } KMO test & 0.638 & 0.562 & 0.552 & 0.541 \\
\hline
\end{tabular}

It is difficult to compare this indicator method to others in pure values since it has different metric systems and variables included. Nevertheless, it can be stated that regression methods similarly follow price movement trends but are sharply approximated with statistical calculations and error corrections, while z-score retains a more natural movement of the market. The UBS bubble index similarly concluded that all 4 metropolitan areas were in overvalued positions, and the normal distribution theorem indicated the same doubt period after the bubble burst. 


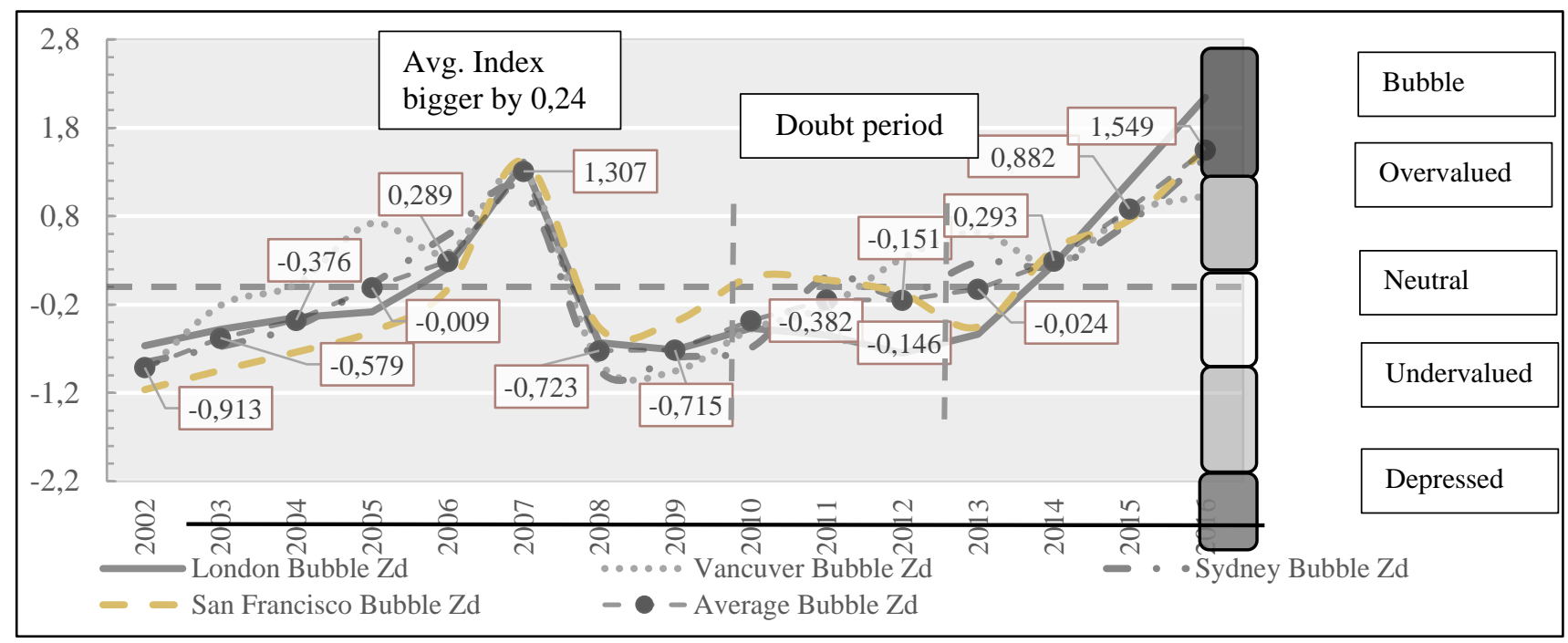

Figure 4. London, San Francisco, Sydney and Vancouver RE market stability indicator for 2002-2016 (compiled by the author)

\section{Conclusions}

As previously used instruments were not sufficient for bubble detection in 2007, the authors of this article took up the challenge to create a more accurate model. Most of the methods employed in scientific papers were either too simplistic and showed an incomprehensive view of the whole market, or missed one or two important variables, while mathematical methods vigorously approximated market movements distorting the reality. The scientific literature analysis has enabled to identify some alternative and promising methods, like factor analysis and Z-scores, which are yet to be more widely applied. The studies on Zscores revealed an accuracy rate of $90 \%$ in predicting risk and bankruptcy among banks and companies, while factor analysis had strong predicting capabilities tested against other methodologies. While using the factor analysis, KMO and Bartlett tests allowed to proceed with expectation variable alongside other scientifically most important six sub-indexes. Expectation variable, which was obtained in the form of a survey carried out by the IGN company, made the real estate stability model more in-depth and versatile since subjective variables play a major role as speculation rises. On the basis of the analysis of many types of research, the other best six variables applicable for evaluation of the market conditions are concluded to be as follows: P/E, P/R, construction, mortgages to GDP change, population and the difference in prices between inside and outside the city centre. The total variance matrix revealed that $\mathrm{P} / \mathrm{E}$ and $\mathrm{P} / \mathrm{R}$ explained more than $70 \%$ of the variance combined, however, other $30 \%$ (in some cases more, in some cases less) remained unexplained.

The analysis of solely $\mathrm{P} / \mathrm{E}$ and $\mathrm{P} / \mathrm{R}$ ratios and mortgage measures has revealed the output gap between prices and income/rent is worsening, which indicates instability in the market. In Sydney, San Francisco, Vancouver and London the price to income difference has grown by $57 \%, 57 \%, 59 \%$ and $33 \%$ respectively. Mortgage cover rate in Sydney was equal to $89.14 \%$, in Vancouver - to $86.63 \%$, in San
Francisco - to $81.88 \%$, and London - to $192 \%$. All of these results exceeded the standard sustainable levels. The priceto-rent values of the state-strategic planning were abnormal for all four cities, but only London had the unstable strategic planning rates which reached about 8 points index difference. A passive strategic planning and an influx of millions of economical immigrants did push London to its extreme value positions. It also means that the demand for real estate in these specific areas has reached its price ceilings since fewer and fewer people are able to afford housing. The constructed real estate market stability index did show similar abnormalities. In 2016, San Francisco already reached 1.56, Vancouver -1.03, and Sydney -1.45 index points; all of the cities were in overvalued positions, while San Francisco fell into a bubble risk area, which is indeed a concerning factor. But the most extreme situation was found in London, the capital of the UK: this metropolitan area scored 2.14 position points. Knowingly, it was concluded that all 4 metropolitan areas have an unstable real estate market situation, which may lead to a severe market correction in the long term. It could be argued that post-2008 actions, taken by the governments and central bank agencies, were sufficient to restore the growth, but, in fact, they were not effective at developing a more sustainable price growth point forward. Hence, the underlying causes of why unstable market conditions occur should be found, and the appropriate action must be taken.

Although it is difficult to compare this index to others solely because of different metric systems and variables, in an abstract sense it provides similar results to UBS factor analysis and zero distribution theorem and mimics the movement of the market in a more natural way than regression equations. It is also troublesome to create regression or any other model to compare the methodologies at face value because of the short nature of this paper. 


\section{References}

ABNS. (2016). Australian Bureau of National Statistics Database. Available from the internet: http://abs.gov.au/

Andrew, M. (2003). House Price Appreciation, Transactions and Structural Change in the British Housing Market: A Macroeconomic Perspective. Journal of Real Estate Economics. 31(1), 99-116. https://doi.org/10.1111/j.10808620.2003.00059.x

Belke, A., \& Wiedmann, M. (2005). Boom or Bubble in the US Real Estate Market? Journal of Intereconomics, 40(5), 273284. https://doi.org/10.1007/s10272-005-0157-0

Bork, L., \& Stig, V. (2016). Housing price forecastability: A factor analysis. Journal of Real Estate Economics., 0, 1-30. http://dx.doi.org/10.1111/1540-6229.12185

Bhattacharya, U. \& Yu, X. (2008). The Causes and Consequences of Recent Financial Market Bubbles. An Introduction. Review of Financial Studies, 21(1), 3-10. https://doi.org/10.2139/ssrn.1010466

Capozza, D., \& Seguin, P. (1996). Expectations, Efficiency and Euphoria in the Housing Market. Journal of regional Science \& Urban Economics, 26(3-4), 369-386. doi.org/10.1016/0166-0462(95)02120-5.

Census US. (2016). Census bureau of US database. Available from the internet: https://census.gov/

Chen, J., \& Qianjin. H. (2010). Submarket, Heterogeneity and Hedonic Prediction Accuracy of Real Estate Prices: Evidence from Shanghai. International Real Estate Review, 13(2), 190-217. Available from the internet: https://ideas.repec.org/a/ire/issued/v13n022010p190-217.html

Coskun Y., \& Jadevicius A. (2017). Is there a Housing Bubble in Turkey? Journal of Real Estate Management and Valuation, 25 (1), 48-73. https://doi.org/10.1515/remav-2017-0003

Cadil, J. (2009). Housing price bubble analysis - case of the Czech Republic. Economic papers of Prague, 18(1), 38-47. https://doi.org/10.18267/j.pep.340

Deniz, I., \& Marcelo, P. (2010). Exposure to Real Estate in Bank Portfolios. Journal of Real Estate Research, 32(1), 47-74. Available from the internet: https://ideas.repec.org/a/jre/issued/v32n12010p47-74.html

European Commission. (2013). Handbook on Residential Property Prices Indices (RPPIs). Belgium. Publications Office of the European Union. https://doi.org/10.2785/34007

Esteban, M., \& Altuzarra, A. (2008). A Model of the Spanish Housing Market. Journal of Post Keynesian Economics, 69(1), 353-373. https://doi.org/10.2753/PKE0160-3477300303

Frew, J., \& Wilson, B. (2002). Estimating the Connection between Location and Property Value. Journal of Real Estate Practice and Education. 5(1) 17-25. Available from the internet: http://citeseerx.ist.psu.edu/viewdoc/ summary?doi=10.1.1.113.8965

Himmelberg, C., Mayer, C., \& Sinai, R. (2005). Assessing High House Prices: Bubbles, Fundamentals, and Misperceptions. NBER working paper No. 11643. https://doi.org/10.3386/w11643.

Hans, L. (2008). Price Bubbles on the Housing Market: Concept, theory and indicators. Working Paper No. 58. Available from the internet: https://doi.org/10.1108/17538270910939574

Herberta, Z., \& V., Gibler, M. (2014). The effect of new residential construction on housing prices. Journal of Housing Economics, 26, 1-18. https://doi.org/10.1016/j.jhe.2014.06.003

Hayes, K., Hodge, K. \& Hughes, W. (2010). A Study of the Efficacy of Altman's Z to Predict Bankruptcy of Specialty Retail Firms. Economics \& Business Journal, 3(1), 122-134. Available from the internet: http://ecedweb.unom aha.edu/EBJI\% 202010HayesHodgeHughes.pdf.

JLL. (2016). JLL market research datasets. Available from the internet: http://www.jll.com/research

Keizeriene, E. (2016). Nekilnojamojo turto kainu burbulo kompleksinis vertinimas: phd disertation: social science, economics (04S). Kauno university of technology. Kaunas: Technologija.

Kulikauskas, D. (2016). Fundamental housing prices in the Baltic States: empirical approach. Baltic Journal of Economics, 16(2), 53-80. https://doi.org/10.1080/1406099X.2016.1173446

Landvoigt, T., Piazzesi, M., \& Schneider, M. (2015). The Housing Market of San Diego. Journal of American Economic Review, 105(4), 1371-1407. https://doi.org/10.1257/aer.20111662

Lettau, M., \& Ludvigson, S. (2004). Understanding Trend and Cycle in Asset Values: Revaluating the Wealth Effect on Consumption. The American Economic Review, 94(1), 276-299. https://doi.org/10.3386/w9848

Klotz, P., Lin, C., \& Hsu, H. (2016). Modelling property bubble dynamics in Greece, Ireland, Portugal and Spain. Journal of European Real estate research, 9(1), 52-75. https://doi.org/10.1108/JERER-11-2014-0038

Merling, L., \& Baker, D. (2016). The Housing Bubble: Is It Back? Center For Economic and Policy Research, 1-20. Available from internet: http://cepr.net/publications/reports/the-housing-bubble-is-it-back

Mayer, Ch. (2011). Housing Bubbles: A Survey. Annual Review of Economics. Journal of Annual Review of Economics, 3(1), 559-577. https://doi.org/10.1146/annurev.economics.012809.103822 
Meeampol, S., \& Lerskullawat, P. (2014). Applying Emerging Market Z-Score Model to Predict Bankruptcy: A Case Study of Listed Companies in The Stock Exchange of Thailand. Management. Knowledge and learning International conference. Portaroz. Slovenia. Make learn.

Muellbauer, J., \& Murphy, A. (2008). Housing Markets and the Economy: The Assessment. Oxford Review of Economic Policy. 24(1), 1-33. Available from the internet: www.wu.ac.at/fileadmin/wu/d/i/iqv/Gstach/Artikel/Muellbau er_2008.pdf

Mourouzi-Sivitanidou, R. (2012). Analysis of Real Estate. Basic real estate economics. Harward, Harward University. Available on the internet: https://isites.harvard.edu/fs/docs/icb.topic1143374.files/Rena_Chap\%202.pdf

Myrmo, M. (2012). Does Population Growth Affect Housing Bubbles? Master Thesis. Norwegian school of economics. Available from the internet: https://brage.bibsys.no/xmlui/bitstream/handle/11250/169577/Myrmo_2012.p df? sequence $=1$

Mustafa, R. (2015). Understanding Real Estate Bubbles: An Analysis of The Recent Trends in The Turkish Housing Market. Master thesis. Middle East Technical University. Available from the internet: https://etd.lib.metu.edu.tr/uplo ad/12618979/index.pdf

Marsden, J. (2015). House prices in London - an economic analysis of London's housing market. Working paper 72. Available from the internet: https://www.london.gov.uk/sites/default/files/house-prices-in-london.pdf

Numbeo. (2016). Numbeo user contribute database. Available from the internet: https://www.numbeo.com/cost-of-living/

ONS. (2016). Office for national statistics database. Available from the internet: https://www.ons.gov.uk

OECD. (2008). Handbook on constructing composite indicators methodology and user guide. France. Available on the internet: https://www.oecd.org/std/42495745.pdf

Pressley, S. (2016). Population influence on property prices. Article. Propertyology research. Available from the internet: http://www.propertyology.com.au/population-growth-doesnt-have-the-influence-that-you-think/

Pitros, C., \& Arayici, Y., (2016). How to identify housing bubbles? A decision support model. International Journal of Housing Markets and Analysis, 9(2), 190-221. https://doi.org/10.1108/IJHMA-01-2015-0002

Pinheiro, M. (2009). Three Cycles: Housing, Credit, and Real Activity. International Monetary Fund. IMF working paper 231, 1-32. Available from the internet: https://papers.ssrn.com/sol3/papers.cfm?abstract_id=1493548

Serena, Ng., Emanuel, Moench. (2010). A Hierarchical Factor Analysis of US Housing Market Dynamics. The Econometrics Journal, 14(1). doi.org/10.1111/j.1368-423X.2010. 00319.x

Shiller, R. (2007). Understanding Recent Trends in House Prices and Homeownership in Housing, Housing Finance, and Monetary Policy. Proceedings Economic Policy Symposium. FRB of Kansas City. 89-123. (Doi): 10.3386/w13553

Sjoling, B. (2012). Indicators for Bubble Formation in Housing Markets. Stockholm. Disertation. Department of Real Estate and Construction. KTH, School of Architecture and the Built Environment. Sweden. Available on the internet https://www.kth.se/polopoly_fs/1.319684!/Menu/general/column-

Statcan. (2016). Statistics Canada Database. Available from the internet: http://www.statcan.gc.ca/

Snieska, V., Venclauskiene, D., Vasiliauskiene, L., \& Gaidelys, V. (2011). The Influence of Transition Economy Pecularities on the Formation of Housing Price Level. Inzinerine Ekonomika-Engineering Economics, 26(4), $357-367$. http://dx.doi.org/10.5755/j01.ee.22.5.973

UBS. (2016). Global Real Estate Bubble Index. UBS Switzerland AG. Available from the internet: ubs.com/global/en/wealth-management/chief-investment-office/key-topics/global-real-estate-bubble-index-2017.html

Towbin, P., \& Weber, S. (2015). Price Expectations and the U.S. Housing Boom. IMF working paper 182(15). Available from the internet: https://www.imf.org/en/Publications/WP/Issues/2016/12/31/Price-Expectations-and-the-U-S-43145

Trulia. (2016). Trullia market research database. Available from the internet: https://www.trulia.com/

Wairimu, J. (2014). The Effect of Macroeconomic Variables on The Value of Real Estates Supplied in Kenya. Master Thesis University of Nairobi. Available from the internet: http://erepository.uonbi.ac.ke/handle/11295/74930

Wooldridge, J. (2002). Econometric Analysis of Cross Section and Panel Data. London. THE MIT Press.

Yifei, L., Huawei, \& X., Junping, J. (2009). Study on Measuring Methods of Real Estate Speculative Bubble. Journal of Service Science and Management, 2(1), 43-46. https://doi.org/10.4236/jssm.2009.21006

Yi, Wang. (2012). Z-score Model on Financial Crisis Early-Warning of Listed Real Estate Companies in China: a Financial Engineering Perspective. Systems Engineering Procedia, 3, 153-157. https://doi.org/10.1016/j.sepro.2011.11.021

Zahirovich, H., \& Karen V. (2014). The Effect of New Residential Construction on Housing Prices. Journal of Housing Economics, 26, 1-18. https://doi.org/10.1016/j.jhe.2014.06.003

Zillow. (2016). Zillow research open data. Available from the internet: https://www.zillow.com/research/data

The article has been reviewed.

Received in October, 2017; accepted in April, 2018. 